\title{
A Numerical Classification of Some Thermus Isolates
}

\author{
By J. ANDREW HUDSON, HUGH W. MORGAN* AND ROY M. DANIEL \\ Department of Biological Sciences, University of Waikato, Private Bag, Hamilton, New Zealand
}

(Received 10 July 1985; revised 25 September 1985)

\begin{abstract}
A numerical classification was performed on a collection of 45 Thermus isolates recovered from New Zealand hot pools and on six type strains including $T$. aquaticus and ' $T$. thermophilus'. Unweighted average linking (UPGMA) and single linkage clustering methods were applied to similarity matrices derived from simple matching $\left(S_{S M}\right)$ and Jaccard similarity $\left(S_{J}\right)$ coefficients. Differences were observed between phenograms derived from $S_{S M}$ and $S_{J}$ coefficients, indicating that some of the clusters formed were derived from a significant component of negative matches. Test error was estimated at $2.9 \%$. In the UPGMA $/ S_{S M}$ phenogram, seven clusters were formed. A majority of the New Zealand isolates did not cluster with non-New Zealand isolates. Analysis of variance showed that there was a relationship between the composition of the clusters and the temperature and $\mathrm{pH}$ of the source of the isolate. Chi-squared testing showed that, within New Zealand, the geographical source of the isolate had no bearing on the clusters formed.
\end{abstract}

\section{INTRODUCTION}

Members of the genus Thermus are described by Brock (1974) as Gram-negative heterotrophic rods and filaments capable of growing at an optimum $\mathrm{pH}$ of 7.5-7.8 and at an optimum temperature of $70-72^{\circ} \mathrm{C}$. To date, only two species have been validly named, $T$. aquaticus (Brock \& Freeze, 1969) and T. ruber (Loginova \& Egorova, 1975; Loginova et al., 1984). The inclusion of the latter expanded the genus description and now enables the K-2 isolate of Ramaley et al. (1975) to be considered as a member of the genus. Other species which have been described, but not validly named, include ' $T$. thermophilus' (Oshima \& Imahori, 1974) and ' $T$. flavus' (Saiki et al., 1972). Non-pigmented isolates have also been described (Pask-Hughes \& Williams, 1975), including Ramaley's strain XI (Ramaley \& Hixson, 1970). One isolate has been named in association with an enzymological study as ' $T$. caldophilus' (Taguchi et al., 1982) and other strains have been deposited in culture collections as ' $T$. rubens' (ATCC 31556) and ' $T$. lacteus' (ATCC 31557), which are patent strains. Strains ATCC 27737 and NCIB 11245, 11246 and 11247, which are all described as being Thermus species, have not been assigned names.

Thermus spp. are widely distributed in natural, thermally heated waters in the USA (Brock \& Freeze, 1969), Iceland (Pask-Hughes \& Williams, 1977; Cometta et al., 1982 b; Kristjansson \& Alfredsson, 1983), Japan (Saiki et al., 1972), the USSR (Egorova \& Loginova, 1974) and New Zealand (Patel, 1984). They also occur in man-made hot-water environments, for example hot tap-water (Pask-Hughes \& Williams, 1975), laundry and domestic hot-water tanks (Brock \& Boylen, 1973), nuclear power plant cooling systems and water discharged from steel mills (Stramer \& Starzyk, 1981). Stramer \& Starzyk (1981) also reported a low background count in river and lake water where there were no overt thermal additions.

Degryse et al. (1978) performed a number of biochemical and physiological tests on eight Thermus isolates and concluded that there were no major differences between ' $T$. thermophilus', $T$. aquaticus and the other strains tested, which had been isolated from a thermally polluted river in Belgium. They recommended that all the isolates be considered as essentially the same. However, Cometta et al. (1982b) demonstrated considerable variation among 35 Icelandic 
isolates in a small numerical taxonomy analysis using 33 characters, some of which were redundant. The clusters formed did not relate to the temperature of the source of the isolates nor to geographical distribution. Cometta et al. $(1982 b)$ hypothesized that Thermus isolates are genetically unstable, and that it is this feature that enables them to survive in an extreme and changing environment.

This paper reports on the results of a numerical classification performed on 45 New Zealand isolates and six non-New Zealand type-strains.

\section{METHODS}

Source of strains. The sources of the strains used in this study are shown in Table 1, along with the temperature and $\mathrm{pH}$ of the sites from which the isolates originated. Isolates were purified either by enrichment on Castenholz medium D (CMD) broth (Ramaley \& Hixson, 1970) followed by repeated streaking on CMD agar plates [CMD solidified with $3 \%(\mathrm{w} / \mathrm{v})$ Oxoid no. 1 agar] or by direct streaking of pool water onto CMD agar followed by repeated streaking until pure cultures were obtained. Only colonies with cells conforming to the description of the genus Thermus (Brock, 1974) were used in the study. T. ruber was not included because of its low optimum growth temperature and questionable status.

Characters tested. All tests (Table 3) had been pre-selected for use on the basis that they were not redundant, and were capable of being reproduced with an error compatible with that recommended by Sneath \& Johnson (1972). Thus all the tests described were used in the final classification and subsequent calculations.

Cultures on CMD plates or in CMD broth were routinely used as sources of inocula. All agar plates were sealed with masking tape to prevent excessive dehydration during incubation. Broth cultures were not shaken and were used in $10 \mathrm{ml}$ volumes, unless otherwise stated. All incubations were at $70^{\circ} \mathrm{C}$ for $24 \mathrm{~h}$ unless otherwise stated. Enzyme assays were done at $70^{\circ} \mathrm{C}$.

Colony characters. All strains were inoculated onto CMD agar plates, and examined for the production of pitting by individual colonies, colony size and the presence of pigments (Table 3 ).

Temperature range of growth. Samples $(0 \cdot 1 \mathrm{ml})$ of culture were used as inocula in CMD broth medium and incubations were at 45,75 and $80^{\circ} \mathrm{C}$. Growth was recorded after $3 \mathrm{~d}$.

pH tolerance. CMD liquid medium was buffered with $5 \mathrm{mM}$-boric acid $/ \mathrm{NaOH}$ buffer to give a final $\mathrm{pH}$ of 9.5 , and with $0.01 \mathrm{M}$-sodium phosphate buffer to give a final $\mathrm{pH}$ of 6.0 . An inoculum of $0.1 \mathrm{ml}$ of culture was used, and growth was recorded after $3 \mathrm{~d}$.

Carbon source utilization. Carbon sources were tested using a microtitre plate method. The plates (supplied by Nunc) were of the U-bottomed type, which enabled good cell pellet formation. Each well contained $0.1 \mathrm{ml}$ doublestrength medium 162 salts (Degryse et al., 1978), $0.05 \mathrm{ml} 0.02 \mathrm{M}$-sodium phosphate buffer $(\mathrm{pH} \mathrm{7.6)}$ and $0.05 \mathrm{ml}$ $1.6 \%(\mathrm{w} / \mathrm{v})$ carbon source which had been filter sterilized $(0.22 \mu \mathrm{m}$ pore size). Tests were done in duplicate, one well containing in addition L-lysine ( $\left.20 \mu \mathrm{g} \mathrm{ml}^{-1}\right)$, which enables ' $T$. thermophilus' to grow (Degryse et al., 1978). Vitamins were not added. The inoculum was $10 \mu \mathrm{l}$ of a $1 / 10$ dilution of a $24 \mathrm{~h}$ liquid culture in $20 \mathrm{~mm}$-sodium phosphate buffer $(\mathrm{pH} 7.6)$. The edges of the plates were sealed with petroleum jelly and plastic film. Plates were incubated for $48 \mathrm{~h}$ in semi-sealed polythene bags. Growth was scored using a magnifying lens to examine for the presence of turbidity or pellets formed at the bottom of the wells. Growth in either well was scored as positive, although in the majority of cases where growth occurred, both wells were identical.

Degradation of organic compounds. Casein hydrolysis was determined by supplementing CMD agar with $0.1 \%$ (w/v) skim milk (Difco) and 0.5\% (w/v) Hammerstein casein (BDH). Two organisms were streaked onto each plate so that confluent areas of growth approximately $2.5 \mathrm{~cm} \times 2.5 \mathrm{~cm}$ were obtained, and plates were examined after $24 \mathrm{~h}$ for the production of a white precipitate around the margin of growth.

An agar overlay technique was used to test for the degradation of other proteinaceous materials. Approximately $20 \mathrm{ml}$ per plate of CMD agar was poured and allowed to set. An overlay was then poured which contained one of the following: elastin $0.3 \%(\mathrm{w} / \mathrm{v})$, hide powder azure $0.2 \%(\mathrm{w} / \mathrm{v})$ or fibrin $0.2 \%(\mathrm{w} / \mathrm{v})$, all obtained from Sigma. Two organisms were streaked per plate, as above. Plates were incubated for up to $3 \mathrm{~d}$, and examined daily for the presence of clear zones around the margin of growth.

Tween 80 hydrolysis was tested according to the method of Degryse et al. (1978).

Tolerance tests. Minimum inhibitory concentrations (MICs) of antibiotics (Table 3) were determined using a microtitre plate technique. Double-strength CMD broth $(0.1 \mathrm{ml})$ was added to each well followed by $0.1 \mathrm{ml}$ of the appropriate antibiotic solution, which had been filter sterilized as previously described. Inoculation, plate sealing and examination were as for carbon source testing except that incubation was for $24 \mathrm{~h}$. All antibiotics were obtained from Sigma.

Growth in the presence of $2 \%(\mathrm{w} / \mathrm{v}) \mathrm{NaCl}$ or $2.5 \%(\mathrm{w} / \mathrm{v})$ trypticase peptone (BBL) was determined by increasing the appropriate component of CMD to the required concentration. Tubes were examined daily up to $3 \mathrm{~d}$ for growth. 
Biochemical tests. DNAase was tested for by the method of Jeffries et al. (1957). After $48 \mathrm{~h}$ incubation, cell growth was washed from the plates, which were then flooded with $0 \cdot 1 \mathrm{M}-\mathrm{HCl}$. A zone of clearing around or underneath the area of growth was scored as a positive result.

The following substrates were used for the detection of enzyme activity: $p$-nitrophenyl $\alpha$-D-glucopyranoside, $p$ nitrophenyl $\beta$-D-glucopyranoside, $p$-nitrophenyl laurate and $p$-nitrophenyl palmitate (all from Sigma). The assay (Cooper, 1982) comprised $0.8 \mathrm{ml} 0.01 \mathrm{M}$-Tris/HCl buffer, $\mathrm{pH} 7.5$, and $0.1 \mathrm{ml} 8 \mathrm{~mm}-\mathrm{p}$-nitrophenyl substrate dissolved in 2-ethoxyethanol. Tubes were allowed to equilibrate for $5 \mathrm{~min}$ and $0.1 \mathrm{ml}$ of sample, either whole cell suspension or cell-free supernatant, was added and incubated at $70^{\circ} \mathrm{C}$. Tubes were scored for the production of a yellow colouration.

$\beta$-Galactosidase was assayed as described by Gerhardt et al. (1981), on cells grown on CMD supplemented with $0.1 \%(w / v)$ lactose. $\alpha$-Galactosidase was assayed by the same procedure but with $o$-nitrophenyl $\alpha$-Dgalactopyranoside as the substrate, on cells grown on CMD supplemented with $0 \cdot 1 \%(\mathrm{w} / \mathrm{v})$ melibiose. Both assays were run for $1 \mathrm{~h}$.

Nitrate reduction was detected according to Gerhardt et al. (1981), on cultures grown in nitrate broth (Difco; $20 \mathrm{ml}$ per $25 \mathrm{ml}$ bottle). Nitrite production was tested for at 1 and $7 \mathrm{~d}$.

Arbutin degradation was detected by the method of Baird-Parker (1960) and aesculin hydrolysis according to Gerhardt et al. (1981).

Modified triple sugar iron agar comprised $\left(\mathrm{g} \mathrm{l}^{-1}\right)$ : yeast extract $0 \cdot 5$, trypticase peptone $0 \cdot 5$, glucose $0 \cdot 1$, lactose $0 \cdot 5$, sucrose $0 \cdot 5$, ferrous sulphate $0 \cdot 2$, sodium chloride $0 \cdot 008$, sodium thiosulphate $0 \cdot 3$, and phenol red $0 \cdot 024$. Trace elements were added as in CMD medium and the $\mathrm{pH}$ adjusted to 7.7 before autoclaving. Inoculated slopes were examined after $24 \mathrm{~h}$ for any of the reactions described in Gerhardt et al. (1981).

Reduction tests. Methylene blue reduction was tested for by adding one drop of $1 \%(\mathrm{w} / \mathrm{v})$ methylene blue to $24 \mathrm{~h}$ broth cultures, vortex mixing and incubating for a further $1 \mathrm{~h}$. Tubes showing a complete or partial decolourization were scored positive.

Tellurite reduction was tested by the method of Wilkinson \& Jones (1977), using $0.01 \%(w / v)$ potassium tellurite.

Viability. Broth cultures were incubated for $14 \mathrm{~d}$ at $70^{\circ} \mathrm{C}$ and then $0 \cdot 1 \mathrm{ml}$ transferred to a fresh CMD tube which was incubated for a further $24 \mathrm{~h}$ and examined for growth.

CMD plates were inoculated and incubated for $24 \mathrm{~h}$, then stored at $25^{\circ} \mathrm{C}$ for $28 \mathrm{~d}$ in the dark. Subcultures were then made to fresh CMD plates and incubated for $24 \mathrm{~h}$. Plates were scored positive for confluent growth of inoculum.

Culture pH. CMD broth tubes were inoculated and incubated. The $\mathrm{pH}$ of the cell suspension was recorded after the tubes had equilibrated to room temperature.

Calculation of test error. At the commencement of the study, 14 cultures were prepared in duplicate and each subculture treated as a separate isolate throughout the test procedures. Error was estimated from these replicates by the method of Sneath \& Johnson (1972), which computes the probability of obtaining an erroneous result from the proportion of mismatches found between the replicate strains.

Analysis of results. The 65 unit characters used were scored as one of two mutually exclusive states, plus ( + ) or minus $(-)$; missing values were encoded so that they were omitted by the computer program. Data were analysed using the cluster analysis facilities of the GENSTAT program (Numerical Algorithms Group, Rothamsted Experimental Station, Harpenden, UK). Similarity matrices were calculated with the simple matching ( $S_{S . M}$; Sokal \& Michener, 1958) and Jaccard ( $S_{J}$; Sneath, 1957) coefficients and clustering was by both single and group pair average (UPGMA) methods, and expressed in the form of phenograms or minimum spanning trees. The facilities of GENSTAT were also used for analysis of variance.

\section{RESULTS}

Experimental error. Error was estimated at $2.9 \%$, which is well within the acceptable range suggested by Sneath \& Johnson (1972).

Clustering of the isolates. From the $S_{S M} /$ UPGMA analysis, seven clusters which each contained more than two different isolates were formed at or above the $73 \%$ similarity level (Fig. 1). These have been labelled A to G. In addition there were four two-member clusters and four single-member clusters.

The $S_{J}$ /UPGMA phenogram showed some differences from Fig. 1 (data not shown). These differences indicate that some of the clusters shown in Fig. 1 may reflect a significant component of negative matches. Irrespective of the similarity coefficient used, clusters $D$ and $E$ remained almost identical. In the $S_{J}$ analysis, one member of cluster A moved to cluster B; cluster $\mathrm{C}$ split into a two-member cluster and a single-member cluster; cluster $\mathrm{F}$ split into two 


\section{Table 1. Thermus isolates used}

The isolates are arranged in the order of the clusters shown in Fig. 1, with their source temperature and pH where known.

\begin{tabular}{|c|c|c|c|c|}
\hline Cluster & Isolate* & $\begin{array}{c}\text { Country of } \\
\text { origin }\end{array}$ & $\begin{array}{c}\text { Source } \\
\mathrm{pH}\end{array}$ & $\begin{array}{c}\text { Source } \\
\text { temp. }\left({ }^{\circ} \mathrm{C}\right)\end{array}$ \\
\hline A & ATCC 31674 (T351) & NZ & $8 \cdot 7$ & 96.4 \\
\hline A & OK6 & NZ & $8 \cdot 2$ & $102 \cdot 5$ \\
\hline A & Rtl & NZ & NA & 85 \\
\hline A & $\mathrm{Rt4} \mathrm{Al}$ & NZ & $7 \cdot 2$ & 87 \\
\hline A & $\mathrm{OKJ}$ & $\mathrm{NZ}$ & $7 \cdot 3$ & 98 \\
\hline A & Wai6 & $\mathrm{NZ}$ & $8 \cdot 5$ & 80 \\
\hline A & $\mathrm{Oh} \mathrm{Al}$ & $\mathrm{NZ}$ & 7 & 80 \\
\hline A & Wais & $\mathrm{NZ}$ & $8 \cdot 5$ & 80 \\
\hline A & Wai4 & $\mathrm{NZ}$ & $8 \cdot 2$ & 94 \\
\hline B & Rt6 Al & $\mathrm{NZ}$ & 9 & 70 \\
\hline B & Tok21 & $\mathrm{NZ}$ & NA & NA \\
\hline B & Tok20 & $\mathrm{NZ}$ & 7 & 86 \\
\hline- & Wai33 A3 & $\mathrm{NZ}$ & $7 \cdot 3$ & 73 \\
\hline- & Wai5 & $N Z$ & $7 \cdot 7$ & 70 \\
\hline $\mathrm{C}$ & Oh $\mathrm{A} 2$ & $\mathrm{NZ}$ & 7 & 80 \\
\hline $\mathrm{C}$ & B5 (Rt pool I) & $\mathrm{NZ}$ & NA & NA \\
\hline $\mathrm{C}$ & B7 (Rt pool 6) & $\mathrm{NZ}$ & $\mathrm{NA}$ & NA \\
\hline- & OK 4 & NZ & 6.9 & 60 \\
\hline D & Tok8 & $\mathrm{NZ}$ & $5 \cdot 6$ & $77 \cdot 5$ \\
\hline D & WK V3 & $\mathrm{NZ}$ & NA & 66 \\
\hline D & Wai28 Al & $\mathrm{NZ}$ & $7 \cdot 4$ & $75 \cdot 5$ \\
\hline D & Rt358 Al & $\mathrm{NZ}$ & $7 \cdot 5$ & 82 \\
\hline D & Wai33 A2 & $\mathrm{NZ}$ & $7 \cdot 3$ & $81 \cdot 6$ \\
\hline D & Rt34 & $\mathrm{NZ}$ & $6 \cdot 3$ & 77 \\
\hline D & Tok23 & $\mathrm{NZ}$ & 7 & 97 \\
\hline D & WK V2 & NZ & $6 \cdot 8$ & 83 \\
\hline- & ATCC 27737 & USA & NA & $\mathrm{NA}$ \\
\hline- & HWBS Al & $\mathrm{NZ}$ & 6.5 & 60 \\
\hline $\mathrm{E}$ & Tok3 & $\mathrm{NZ}$ & 6.9 & 76 \\
\hline $\bar{E}$ & OKG & $\mathrm{NZ}$ & $7 \cdot 9$ & 74 \\
\hline $\mathrm{E}$ & Tok 1 & NZ & $7 \cdot 9$ & 96 \\
\hline $\mathrm{E}$ & Tok22 & $\mathrm{NZ}$ & 6.5 & 75 \\
\hline $\mathrm{E}$ & OK2 & $\mathrm{NZ}$ & $7 \cdot 6$ & $57 \cdot 1$ \\
\hline $\mathrm{E}$ & TPI0 & $\mathrm{NZ}$ & $6 \cdot 3$ & $70 \cdot 7$ \\
\hline $\mathrm{E}$ & Ket4 & $\mathrm{NZ}$ & 6 & 80 \\
\hline $\mathrm{E}$ & $\mathrm{Rt} 4$ & $\mathrm{NZ}$ & $8 \cdot 1$ & 87 \\
\hline $\mathrm{F}$ & ATCC 27978 (Ramaley XI) & USA & NA & 26 \\
\hline $\mathrm{F}$ & Rt39 & $\mathrm{NZ}$ & 4 & $68 \cdot 1$ \\
\hline $\mathrm{F}$ & ATCC 25104 (T. aquaticus) & USA & NA & $71 \cdot 5$ \\
\hline- & NCIB 11245 (strain NH) & UK & NA & NA \\
\hline- & Rt6 A2 & $\mathrm{NZ}$ & 9 & $48 \cdot 4$ \\
\hline G & Wai2 & $N Z$ & $3 \cdot 9$ & 54 \\
\hline $\mathrm{G}$ & Rt366 & $\mathrm{NZ}$ & NA & 76 \\
\hline $\mathrm{G}$ & $\mathrm{Rt} 8 \mathrm{Al}$ & $\mathrm{NZ}$ & $9 \cdot 1$ & 77 \\
\hline $\mathrm{G}$ & Rt35 & NZ & $6 \cdot 6$ & 80 \\
\hline $\mathrm{G}$ & Rt 355 & NZ & $7 \cdot 3$ & 81 \\
\hline- & B2 (unrecorded Ket pool) & NZ & NA & NA \\
\hline- & HWBS A2 & $\mathrm{NZ}$ & $6 \cdot 5$ & 60 \\
\hline- & NCIB 11247 (strain B) & Iceland & $8 \cdot 9$ & 82 \\
\hline- & Fiji3 & Fiji & $7 \cdot 5$ & $85 \cdot 4$ \\
\hline - & ATCC 27634 ('T. thermophilus') & Japan & $6 \cdot 3$ & 80 \\
\hline
\end{tabular}

NA, Not available.

* Abbreviations used: ATCC, American Type Culture Collection, Rockville, Md., USA; NCIB, National Collection of Industrial Bacteria (now NCIMB), Aberdeen, UK. New Zealand hot-pool locations: Tok-, Tokaanu; Wai-, Waimangu; Rt-, Rotorua; OK-, Orakeikorako; TP-, Taupo; Oh-, Ohaaki; HWBS-, Hot Water 


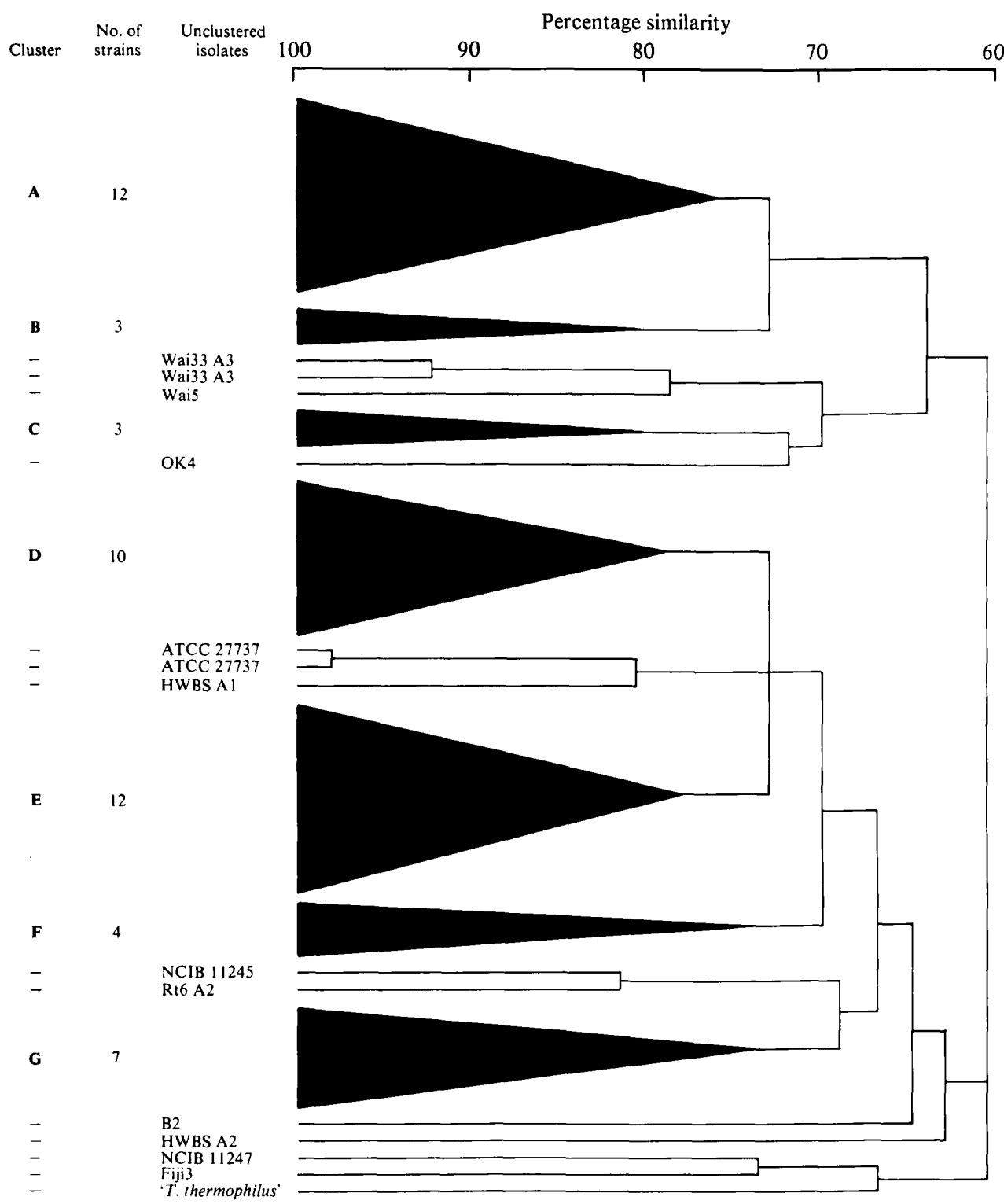

Fig. 1. Simplified phenogram based on the UPGMA analysis of a similarity matrix derived from the $S_{S M}$ coefficient.

single-member clusters and a cluster of a replicate pair; and cluster $G$ lost two members which formed a separate two-member cluster.

Single linkage analyses were represented as minimum spanning trees (data not shown) and showed groupings of organisms similar to those obtained by UPGMA analysis. In both cluster

Beach Springs: WKV-, Waikite Valley; Ket-, Ketatahi. Non-New Zealand location: Fiji-, Savu Savu beach. Isolate nomenclature: the general format used represents the thermal region from which the isolate originated and the pool number in that region followed by, if appropriate, 'A' (aerobe) and a serial number for the isolate (e.g. Wai33 A2 is the second aerobic isolate from pool 33 at Waimangu). 
Table 2. Analysis of variance between clusters for temperature and $\mathrm{pH}$ of isolate source

\begin{tabular}{|c|c|c|c|c|}
\hline $\begin{array}{l}\text { Source of } \\
\text { variation }\end{array}$ & $\begin{array}{l}\text { Sums of } \\
\text { squares }\end{array}$ & $\begin{array}{l}\text { Degrees of } \\
\text { freedom }\end{array}$ & $\begin{array}{c}\text { Mean } \\
\text { squares }\end{array}$ & $\begin{array}{c}\text { Variance } \\
\text { ratio }\end{array}$ \\
\hline \multicolumn{5}{|c|}{ Temperature of isolate source } \\
\hline $\begin{array}{l}\text { Between clusters } \\
\text { Residual } \\
\text { Total }\end{array}$ & $\begin{array}{l}3166 \cdot 4 \\
3821 \cdot 7 \\
6988 \cdot 1\end{array}$ & $\begin{array}{r}6 \\
29 \\
35\end{array}$ & $\begin{array}{l}527 \cdot 7 \\
131 \cdot 8\end{array}$ & $4 \cdot 005^{* *}$ \\
\hline \multicolumn{5}{|c|}{$p H$ of isolate source } \\
\hline $\begin{array}{l}\text { Between clusters } \\
\text { Residual } \\
\text { Total }\end{array}$ & $\begin{array}{l}17 \cdot 86 \\
26 \cdot 73 \\
44 \cdot 59\end{array}$ & $\begin{array}{r}6 \\
24 \\
30\end{array}$ & $\begin{array}{l}2 \cdot 98 \\
1 \cdot 11\end{array}$ & $2 \cdot 67^{*}$ \\
\hline
\end{tabular}

Table 3. Percentage frequency of positive results for clustered organisms derived from $S_{S M} / U P G M A$ analysis

Character

'Pitted' colonies

Colonies $>3 \mathrm{~mm}$

Yellow/orange colonies

Growth at:

$45^{\circ} \mathrm{C}$

$75^{\circ} \mathrm{C}$

$\mathrm{pH} 9 \cdot 5$

pH 6

Utilization of carbon sources:

Acetate

Melibiose

Glutamate

Maltose

Succinate

Pyruvate

Glucose

Mannose

Rhamnose

Mannitol

Sucrose

Sorbitol

Fructose

Acctamide

Proline

Galactose

Lactose

Hydrolysis of :

Casein

Elastin (24 h)

Elastin (72 h)

Fibrin (24 h)

Fibrin (72 h)

Tween 80

Antibiotic MICs $\left(\mu \mathrm{g} \mathrm{ml}^{-1}\right)$ :

Chloramphenicol MIC $>1.25$

Phosphomycin MIC $>12.5$

Spectinomycin MIC $>6$

Kanamycin MIC $>0.6$

Cycloserine MIC $>12.5$

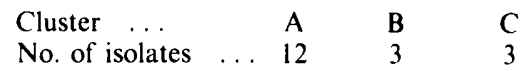

$\begin{array}{rrr}8 & 0 & \\ 8 & 0 & \\ 100 & 100 & 100 \\ 100 & 100 & 100 \\ 92 & 100 & 100 \\ 0 & 0 & \\ 92 & 100 & 66\end{array}$

$\begin{array}{rr}100 & 100 \\ 92 & 100\end{array}$

$\begin{array}{rrr}92 & 100 & 0 \\ 100 & 100 & 33\end{array}$

$\begin{array}{lll}100 & 100 & 33\end{array}$

$\begin{array}{lll}75 & 33 & 33\end{array}$

25

25

83

42

42

92

50

0

42

100

92

100

67

0

33

0

100

0
67

67
0

100

100

100

$\begin{array}{ll}75 & 100\end{array}$

100

100

83

100

92

0

67

100

100

100

$92 \quad 100$

$67 \quad 33$

$92 \quad 100$

$33 \quad 33$

$0 \quad 33$

Growth in:

$2 \% \mathrm{NaCl}$

$2.5 \%$ peptone

Presence of DNAase

$\begin{array}{rrrrrrr}8 & 0 & 0 & 0 & 0 & 0 & 0 \\ 75 & 0 & 66 & 40 & 50 & 75 & 0 \\ 92 & 33 & 66 & 80 & 83 & 75 & 100\end{array}$


Table 3 (continued)

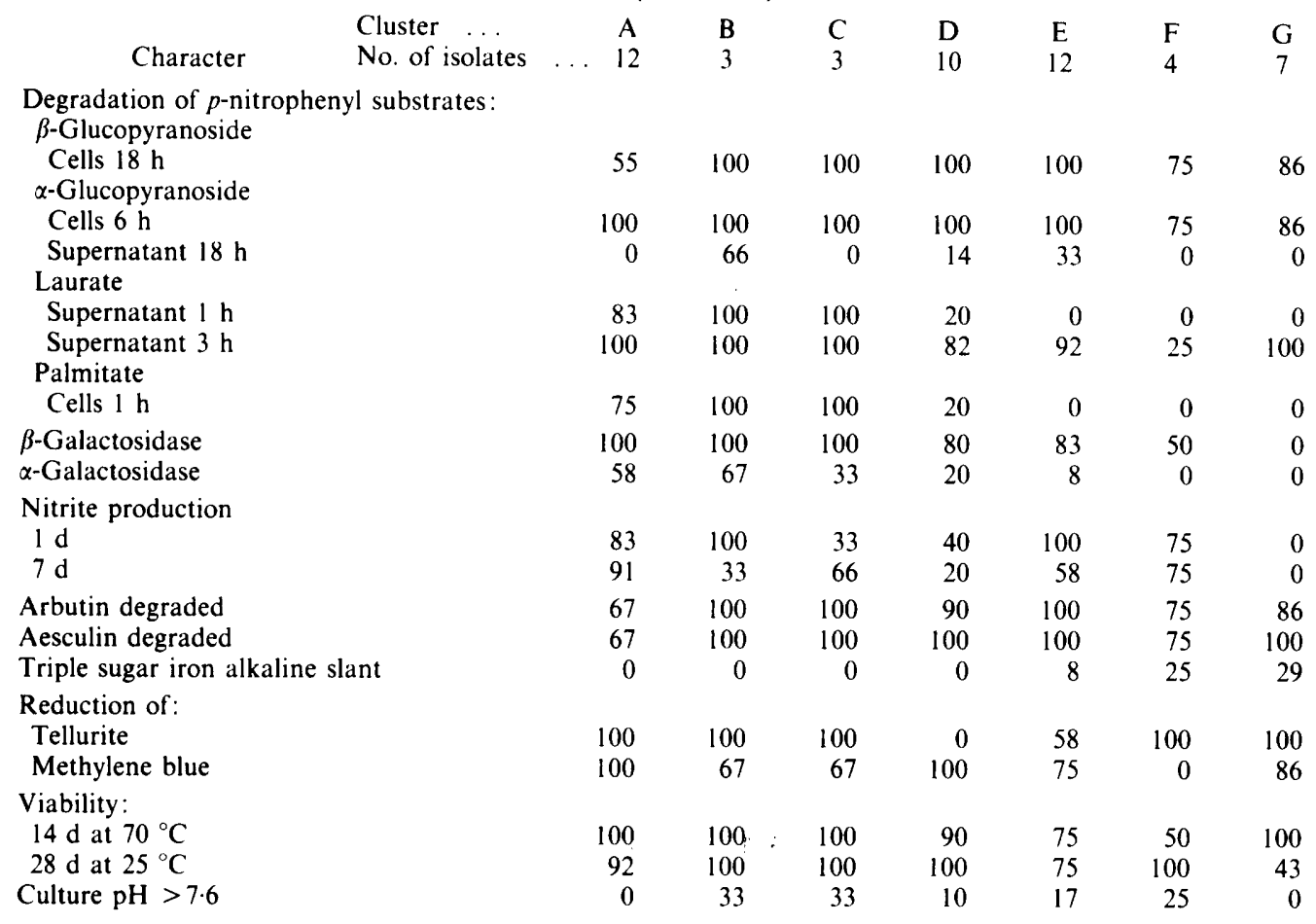

No clustered strains grew at $80^{\circ} \mathrm{C}$. All clustered strains had hydrolysed hide powder azure after $48 \mathrm{~h}$.

analyses, organisms B2, HWBS A1, HWBS A2 and ATCC 27737 remained as single-member clusters. $T$. aquaticus clustered with a minor cluster in the $S_{S M}$ analysis but not with any in the $S_{J}$ analysis, whereas ' $T$. thermophilus' did not cluster with any group when either method was employed. Only cluster F contained isolates which were not from New Zealand sources, other non-New Zealand isolates were restricted to single- or two-member clusters. It would seem, therefore, that the bulk of the New Zealand isolates are different from strains from other parts of the world.

The four strains lacking a yellow or orange pigment, HWBS A1, HWBS A2, 'Ramaley XI' and NCIB 11245, did not cluster together, indicating that lack of pigment is not a good character for identification.

In an attempt to discern some pattern to the clusters, a chi-squared test was done to compare the distribution of the New Zealand geographical isolate sites within the clusters, with that which could be expected by random distribution; there were no major deviations from the random distribution. Therefore, the composition of clusters could not be related to the geographical source of the isolate within New Zealand.

An analysis of variance was done, using the appropriate facility of the GENSTAT program, on the two known environmental parameters of isolate sources. The $\mathrm{pH}$ and temperature values for members of each cluster were compared with the values from each other cluster using a single-factor analysis of variance. The distribution of $\mathrm{pH}$ and temperature between the clusters was shown to be such that the null hypotheses of each cluster having equal $\mathrm{pH}$ means and equal temperature means could be rejected (Table 2). Therefore, the members of each cluster tended to be derived from pools with similar $\mathrm{pH}$ and temperature values, This was not a rigid rule, as isolates from the same pool could be found to cluster separately, for example Wai33 A2 and Wai33 A3, which were isolated from the same sample, clustered in group D and a two-member cluster respectively.

Characterization of the isolates. The distribution of positive characters among clusters with the $S_{S M} /$ UPGMA analysis is presented in Table 3 , and a list of tests useful for the identification of 
Table 4. Differential characteristics of the cultures ,+- and $v$ correspond to $\geqslant 80 \%, \leqslant 20 \%$ and $21-79 \%$ positive responses respectively.

\section{Character}

Potassium tellurite reduction

Elastin degradation $(24 \mathrm{~h})$

Growth at $45^{\circ} \mathrm{C}$

Laurate degradation (supernatant $1 \mathrm{~h}$ )

Fibrin degradation $(24 \mathrm{~h})$

A
+
+
+
+
+

Cluster
D
-
-
+
-
-

$\begin{array}{lll}\text { E } & \text { F } & \text { G } \\ \text { v } & + & + \\ \text { v } & + & - \\ + & - & \text { v } \\ - & - & - \\ + & + & \text { v }\end{array}$

the clusters is given in Table 4. In general, the colony characteristics could not be used diagnostically, and neither could growth at extremes of $\mathrm{pH}$. Cluster $\mathrm{F}$ had no member able to grow at $45^{\circ} \mathrm{C}$. Different clusters showed different carbon source utilization patterns. Members of clusters $\mathrm{A}, \mathrm{B}$ and $\mathrm{E}$ were able to use a wide range of carbon compounds; members of clusters $C, D, F$ and $G$ were less versatile, showing low percentage positives for the few carbon compounds that they were able to use. Members of clusters $\mathrm{C}$ and $\mathrm{D}$ were generally poorly proteolytic. There appeared to be no pattern to Tween 80 degradation.

Members of clusters C, F and $\mathrm{G}$ were sensitive to chloramphenicol, while those of clusters $\mathrm{F}$ and $G$ were sensitive to phosphomycin, and those of cluster $G$ were also sensitive to kanamycin. No member of clusters $B$ or $G$ was able to grow in the presence of $2.5 \%(w / v)$ trypticase peptone.

Members of clusters $\mathrm{A}, \mathrm{B}$ and $\mathrm{C}$ showed high percentage positives for $p$-nitrophenyl palmitate degradation, while most of the isolates tested could degrade $p$-nitrophenyl laurate. $\beta$ Galactosidase was produced by most organisms, while very few were able to produce $\alpha$ galactosidase; cluster $\mathrm{B}$ showed the highest percentage positives able to produce the latter.

No member of cluster $D$ was able to reduce tellurite, and no member of cluster $F$ was able to reduce methylene blue. Nitrate was not reduced by any member of cluster $G$.

Many other tests such as arbutin and aesculin degradation, triple sugar iron reactions and culture viability did not produce diagnostically useful results.

\section{DISCUSSION}

In a numerical classification of Icelandic Thermus isolates, Cometta et al. (1982b) were not able to show any correlation between the sources of their isolates and the clusters formed. The data presented here agree with this aspect of their findings, at least with regard to the New Zealand isolates. The fact that the bulk of New Zealand isolates did not cluster with isolates from other countries may indicate that geographical variation is important between distant regions. In support of this conclusion the phenogram produced by Cometta et al. (1982b) showed two Japanese isolates, ' $T$. flavus' and ' $T$. thermophilus', in a distinct cluster from their Icelandic isolates.

The data presented here indicate that the phenotype present at any one location may be determined by the environmental conditions prevailing; the clusters formed were related to the temperature and $\mathrm{pH}$ of the sources of the isolates in those clusters. The effect on the distribution

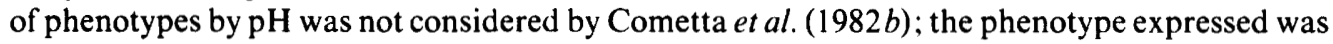
attributed by them primarily to the temperature of the organism's environment. There may be a number of other factors which also play a part in determining which phenotypes are present (for example, the presence of sulphide or toxic metals), knowledge of which could further explain the clusters produced by both this classification and that of Cometta et al. (1982b). The methods used for isolation also determine the phenotype which is found, although in this study direct streaking of pool water onto CMD agar plates was the method used whenever possible so that the most common phenotype was isolated, and not necessarily the fastest growing, which may be the case with liquid enrichment. 
Based on the evidence of their numerical classification and on previous work with Thermus isolates in continuous culture (Sonnleitner et al., 1982; Cometta et al., 1982a), Cometta et al. $(1982 b)$ suggested that there is a high degree of genetic instability within members of the genus. Our results confirmed that there is phenotypic variability, but they do not confirm or refute the hypothesis of genetic instability. An alternative to the suggestion of genetic instability is that any one pool, or thermal environment of the correct type (neutral or alkaline $\mathrm{pH}$ ), contains a population of Thermus phenotypes, any one of which is numerically dominant (and hence the most likely to be isolated). Conditions in hot pools vary within any one pool, both with time (Patel et al., 1985) and with distance (e.g. the water cools in runoff channels), and they also vary between pools. It may be, therefore, that the dominant phenotype at a particular time and location is determined by the conditions prevailing at that site by selection of a strain, from a population of strains, which is best suited to growth under those conditions.

A study of the population ecology of Sulfolobus acidocaldarius (Mosser et al., 1974; Bohlool \& Brock, 1974) showed that a mixture of strains occurred in the hot pools studied, indicating heterogeneity amongst the isolates. Heterogeneity was shown by optimum temperature, immunofluorescence and immunodiffusion studies of hot spring populations, so in at least one other group of thermophilic micro-organisms the same heterogeneity of isolates as our results indicate has been found.

With regard to the taxonomy of these bacteria, like the study of Cometta et al. (1982b) our results show considerable variety within the isolates studied. The validly named species, $T$. aquaticus, does not show a close taxonomic relationship to the New Zealand isolates or to ' $T$. thermophilus', which was isolated in Japan. If the major clusters formed represent different species, then the genus is clearly comprised of many species. However, the data are still far from complete because of the apparent influence of geography on the phenotype isolated, and it may be that different thermal areas will be shown to have regionally specific clusters and perhaps other clusters which overlap with those from other thermal areas. Therefore, any revision of the taxonomy would require that more isolates, from a comprehensive range of world-wide sources, be examined.

Further work is underway to compare New Zealand Thermus isolates to those from other thermal areas of the world, and also to see if phenotype changes with time in New Zealand hot springs.

This work was partly funded by the Development Finance Corporation of New Zealand. We thank Dr C. G. Harfoot and Andrea Martin for helpful comments during preparation of the manuscript.

\section{REFERENCES}

BAIRD-PARKer, A. C. (1960). The classification of fusobacteria from the human mouth. Journal of General Microbiology 22, 458-469.

Bohlool, B. B. \& BRock, T. D. (1974). Population ecology of Sulfobolus acidocaldarius. II. Immunoecological studies. Archives of Microbiology 97, 181194.

Brock, T. D. (1974). Genus Thermus. In Bergey's Manual of Determinative Bacteriology, 8th edn, p. 285. Edited by R. E. Buchanan \& N. E. Gibbons. Baltimore: Williams \& Wilkins.

Brock, T. D. \& Boylen, K. L. (1973). Presence of thermophilic bacteria in laundry and domestic hot water heaters. Applied Microbiology 25, 72-76.

Brock, T. D. \& FrEeze, H. (1969). Thermus aquaticus gen. n. and sp. n., a non-sporulating extreme thermophile. Journal of Bacteriology 98, 289-297.

Cometta, S., Sonnleitner, B. \& Fiechter, A. $(1982 a)$. The growth behaviour of Thermus aquaticus in continuous cultivation. European Journal of Applied Microbiology and Biotechnology 15, 69-74.
Cometta, S., Sonnleitner, B., Sidler, W. \& FiechTer, A. (1982b). Population distribution of aerobic extremely thermophilic microorganisms in an Icelandic hot spring. European Journal of Applied Microbiology and Biotechnology 16, 151-156.

COOPER, A. B. (1982). Studies on soil and microbial lipases. DPhil thesis, University of Waikato, Hamilton, New Zealand.

Degryse, E., Glansdorff, N. \& Pierard, A. (1978). A comparative analysis of extreme thermophilic bacteria belonging to the genus Thermus. Archives of Microbiology 117, 189-196.

Egorova, L. A. \& Loginova, L. G. (1974). Nonsporulating bacteria from $\mathrm{K}$ amchatka hot sources with a $70-75^{\circ} \mathrm{C}$ optimum growth temperature. Microbiology 43, 758-762.

Gerhardt, P., Murray, R. G. E., Costilow, R. N., Nester, E. W., Wood, W. A., Krieg, N. R. \& PhILliPS, G. B. (editors) (1981). Manual of Methods for General Bacteriology. Washington, DC: American Society for Microbiology. 
JefFries, C. D., Holtman, D. F. \& Guse, D. G. (1957). Rapid method for determining the activity of microorganisms on nucleic acids. Journal of Bacteriology 73, 590-591.

Kristjansson, J. K. \& Alfredsson, G. A. (1983). Distribution of Thermus spp. in Icelandic hot springs and a thermal gradient. Applied and Environmental Microbiology 45, 1785-1789.

Loginova, L. G. \& Egorova, L. A. (1975). An obligately thermophilic bacterium Thermus ruber from hot springs in Kamchatka. Microbiology 44, 593-597.

Loginova, L. G., Egorova, L. A., Golovacheva, R. S. \& Seregina, L. M. (1984). Thermus ruber sp. nov., nom. rev. International Journal of Systematic Bacteriology 34, 498-499.

Mosser, J. L., Mosser, A. G. \& Brock, T. D. (1974). Population ecology of Sulfolobus acidocaldarius. I. Temperature strains. Archives of Microbiology 97, 169-179.

OSHIMA, T. \& IMAHORI, K. (1974). Description of Thermus thermophilus (Yoshida and Oshima) comb. nov., a non sporulating thermophilic bacterium from a Japanese thermal spa. International Journal of Systematic Bacteriology 24, 102-112.

Pask-Hughes, R. \& Williams, R. A. D. (1975). Extremely thermophilic Gram-negative bacteria from hot tap water. Journal of General Microbiology 88, 321-328.

Pask-Hughes, R. \& Williams, R. A. D. (1977). Yellow-pigmented strains of Thermus spp. from Icelandic hot springs. Journal of General Microbiology 102, 375-383.

PATEL, B. K. C. (1984). Extremely thermophilic bacteria in New Zealand hot springs. DPhil thesis, University of Waikato, Hamilton, New Zealand.

Patel, B. K. C., Morgan, H. W. \& Daniel, R. M. (1985). Thermophilic spirochetes in New Zealand hot springs. FEMS Microbiology Letters 26, 101-106.
Ramaley, R. F. Bitzinger, K., Carroll, R. M. \& Wilson, R. B. (1975). Isolation of a new, pink, obligately thermophilic Gram-negative bacterium (K-2 isolate). International Journal of Systematic Bacteriology 25, 357-364.

Ramaley, R. F. \& Hixson, J. (1970). Isolation of a non pigmented, thermophilic bacterium similar to Thermus aquaticus. Journal of Bacteriology 103, 527-528.

SAIKI, T., KimURA, R. \& ARIMA, K. (1972). Isolation and characterization of extremely thermophilic bacteria from hot springs. Agricultural and Biological Chemistry 36, 2357-2366.

SNEATH, P. H. A. (1957). The application of computers to taxonomy. Journal of General Microbiology 17, 201-206.

SNEATH, P. H. A. \& Johnson, R. (1972). The influence on numerical taxonomic similarities of errors in microbiological tests. Journal of General Microbiology 72, 377-392.

SOKAL, R. R. \& Michener, C. D. (1958). A statistical method for evaluating systematic relationships. Kansas University Science Bulletin 38, 1409-1438.

Sonnleitner, B., Cometta, S. \& Fiechter, A. (1982). Growth kinetics of Thermus thermophilus. European Journal of Applied Microbiology and Biotechnology 15, 75-82.

Stramer, S. L. \& Starzyk, M. J. (1981). The occurrence and survival of Thermus aquaticus. Microbios 32, 99-110.

Taguchi, H., Yamishta, M., Matsuzawa, H. \& Ohta, T. (1982). Heat-stable and fructose 1,6-bisphosphate-activated L-lactate dehydrogenase from an extremely thermophilic bacterium. Journal of Biochemistry 91, 1343-1348.

Wilkinson, B. J. \& Jones, D. (1977). A numerical survey of Listeria and related bacteria. Journal of General Microbiology 98, 399-421. 